\title{
Phytopreventive Effect of Buah Merah (Pandanus conoideus Lam.) Oil In Colitis-Associated Carcinogenesis
}

\author{
Oeij Anindita Andhika \\ Department of Anatomy, Faculty of Medicine, Maranatha Christian University \\ Jln. Prof. Drg. Suria Sumantri MPH no 65 Bandung 40163 Indonesia \\ Email :anindita_andhika@yahoo.com
}

\begin{abstract}
Colorectal cancer has provided a paradigm for the connection between inflammation and cancer. Modulation of intracellular signaling involved in chronic inflammatory response by anti-inflammatory agents represents an important strategy in molecular target-based chemoprevention. The aim of this research is to study the effect of buah merah oil on IL-6 serum level and histopathology of colon in colitis-associated cancer (CAC) mice model. BALB/c mice were randomly divided into four groups. The negative control and buah merah control were given aquabidest and buah merah, respectively, without CAC induction. The AOM/DSS control and buah merah treatment were given azoxymethane (AOM) followed by dextran sulfate sodium (DSS) to induce CAC. The AOM/DSS control was given aquabidest while the buah merah treatment was given buah merah. Data were analyzed by One-Way ANOVA continued with Tukey-HSD. The result showed that IL-6 level in mice administrated with buah merah was significantly lower than the AOM/DSS control $(p=0.000)$. Histopathological analysis scores of colon were analyzed by Kruskal-Wallis continued with Mann-Whitney. The result showed that histopathological analysis score in buah merah treatment was significantly lower than in the AOM/DSS control $(p=0.002)$. Taken together, buah merah oil lowered IL-6 level and histopathological analysis score of colon in CAC mice model.
\end{abstract}

Keywords: CAC, buah merah oil, IL-6 level, histopathological analysis scores of colon 


\title{
Efek Fitopreventif Minyak Buah Merah (Pandanus conoideus Lam.) Terhadap Colitis-Associated Carcinogenesis
}

\author{
Oeij Anindita Andhika \\ Bagian Anatomi, Fakultas Kedokteran Universitas Kristen Maranatha Bandung \\ Jln. Prof. Drg. Suria Sumantri MPH no 65 Bandung 40163 Indonesia \\ Email : anindita_andhika@yahoo.com
}

\begin{abstract}
Abstrak
Kanker kolorektal mewakili paradigma hubungan antara inflamasi dan kanker. Modulasi intracellular signaling yang terlibat dalam respon inflamasi kronik oleh agen antiinflamasi menjadi strategi penting dalam upaya kemoprevensi yang didasarkan pada target molekular. Penelitian ini bertujuan mengetahui efek fitopreventif minyak buah merah terhadap kadar IL-6 serum dan histopatologi kolon pada mencit model colitis-associated cancer (CAC). Mencit galur BALB/c dikelompokkan secara acak menjadi 4 kelompok. Kelompok kontrol negatif diberikan aquabidest dan kelompok kontrol buah merah diberikan minyak buah merah, tanpa diinduksi CAC. Kelompok kontrol AOM/DSS dan kelompok perlakuan buah merah diinduksi CAC dengan azoxymethane (AOM) dan dextran sulfate sodium (DSS). Kelompok kontrol AOM/DSS diberikan aquabidest, sedangkan kelompok perlakuan buah merah diberikan minyak buah merah. Data dianalisis dengan uji ANOVA satu arah dilanjutkan Tukey HSD. Kelompok perlakuan buah merah memiliki rerata kadar IL-6 serum yang lebih rendah dibandingkan kelompok kontrol AOM/DSS $(\mathrm{p}=0,000)$. Skor analisis histopatologis kolon dianalisis dengan uji Kruskal-Wallis dilanjutkan Mann-Whitney. Kelompok perlakuan buah merah memiliki skor analisis histopatologis yang lebih rendah dibandingkan kelompok kontrol AOM/DSS ( $p=0,002)$. Sebagai simpulan, minyak buah merah menurunkan kadar IL-6 serum dan skor histopatologis kolon mencit model CAC.
\end{abstract}

Kata kunci: CAC, minyak buah merah, kadar IL-6, skor analisis histopatologis kolon 


\section{Research Article}

\section{Pendahuluan}

Kanker kolorektal merupakan keganasan tersering ketiga di dunia. Setiap tahun, sekitar satu juta kasus kanker kolorektal didiagnosis di seluruh dunia. ${ }^{1}$ Berdasarkan data yang dihimpun WHO, kanker kolorektal merupakan penyebab kematian akibat kanker tersering keempat, setelah kanker paru, kanker lambung dan kanker hati. ${ }^{2}$ Pada berbagai laporan di Indonesia, ditemukan kenaikan jumlah kasus kanker kolorektal, meskipun belum ada data yang pasti. Data di Kementerian Kesehatan menyatakan insidensi kanker kolorektal adalah 1,8 per 100.000 penduduk. Di Rumah Sakit Kanker Dharmais dan Rumah Sakit Cipto Mangunkusumo, kasus kanker kolorektal termasuk 10 besar kasus kanker. ${ }^{3}$

Studi epidemiologis dan observasi klinis menunjukkan bahwa faktor penyebab lingkungan dan faktor risiko kanker sering berhubungan dengan berbagai bentuk inflamasi kronik. ${ }^{1,4,5}$ Komponen inflamasi juga ditemukan dalam microenvironment tumor yang secara epidemiologis tidak berhubungan dengan kanker. ${ }^{5-7}$ Menurut Hanahan dan Weinberg, ada enam karakteristik esensial sel tumor, yaitu (1) mampu menyediakan sendiri faktor pertumbuhan, (2) tidak sensitif terhadap inhibitor faktor pertumbuhan, (3) mampu menghindar dari apoptosis, (4) memiliki potensi replikasi yang tidak terbatas, (5) dapat membentuk pembuluh darah baru (angiogenesis) dan (6) memiliki kemampuan menginvasi jaringan dan bermetastasis. Saat ini, cancer-related inflammation dianggap sebagai karakteristik kanker yang ketujuh., ${ }^{5,6}$

Inflamasi kronik yang terjadi pada inflammatory bowel disease (IBD) dikaitkan dengan risiko yang meningkat untuk terjadinya kanker kolorektal. Inflammatory bowel disease adalah penyakit inflamasi kronik pada saluran gastrointestinal yang meliputi dua kelainan yaitu Crohn's disease (CD) dan ulcerative colitis (UC). IBD mengenai sekitar 1,4 juta orang di Amerika Serikat dan 2,2 juta orang di Eropa, dan terus meningkat dalam beberapa dekade terakhir. Serangan yang dini, derajat yang berat dan durasi penyakit yang lama semakin meningkatkan risiko terjadinya colitis-associated cancer (CAC). Inflammatory bowel disease merupakan model bagi penelitian yang menelaah dasar mekanisme cancer-related inflammation, yang mana sangat didukung oleh perkembangan berbagai model hewan coba kanker kolorektal. ${ }^{1,4,5}$

Dua jalur selular dan molekular diketahui menghubungkan inflamasi dan kanker: (1) jalur intrinsik, yang mana aktivasi onkogen akan meningkatkan ekspresi inflammation-related protein yang membentuk inflammatory microenvironment; (2) jalur ekstrinsik, kondisi inflamasi kronik mempromosikan perkembangan kanker. ${ }^{5}$ Penelitian-penelitian saat ini difokuskan pada sel inflamasi dan jalur inflamasi yang berperan dalam microenvironment tumor dan berperan penting dalam perkembangan dan progresivitas tumor. ${ }^{8-10}$ 


\section{Research Article}

Komponen kunci cancer promoting inflammation meliputi faktor transkripsi utama (seperti NF-kB, STAT3), sitokin proinflamasi (seperti IL-6), COX-2 dan kemokin tertentu (CCL2). ${ }^{7}$ Hasil penelitian mendukung peran penting interleukin-6 (IL-6) dalam patogenesis IBD dan kanker kolon. ${ }^{11}$ Ekspresi IL-6 sangat mempengaruhi pertumbuhan tumor pada model CAC, menunjukkan fungsinya sebagai faktor tropik bagi sel epitel neoplastik. ${ }^{12}$ IL-6 memodulasi ekspresi kemokin dan molekul adhesi serta apoptosis, menekan infiltrasi neutrofil dan meningkatkan akumulasi leukosit mononuklear, dengan demikian mengatur resolusi inflamasi akut dan aktivasi imunitas adaptif. ${ }^{13}$ Pada studi klinis, kadar tinggi IL-6 dan sIL-6R ditemukan dalam darah tepi penderita IBD, yang mana IL-6 meningkatkan akumulasi sel $\mathrm{T}$ di lamina propria kolon dengan menaikkan regulasi faktor antiapoptotik, yakni Bcl-2 dan Bcl-xl. ${ }^{14,15}$ Hasil penelitian pada penderita UC yang berkembang menjadi CAC, menunjukkan bahwa ekspresi IL-6 dan STAT3 lebih tinggi pada penderita UC aktif dan penderita UC yang berkembang menjadi CAC, dibandingkan pada penderita UC yang tidak aktif dan penderita kontrol. ${ }^{16}$

Inflamasi kronik menghasilkan suatu complex milleu faktor pertumbuhan dan sitokin yang menyebabkan hiperplasia. Sinyal proliferatif dan antiapoptotik yang terjadi pada inflamasi kronik beraksi sinergis dengan kerusakan DNA dalam meningkatkan perkembangan kanker. ${ }^{17}$ Displasia merupakan manifestasi histologik paling dini yang ditemukan pada proses yang menghubungkan inflamasi kronik dengan kanker. ${ }^{18,19}$

Dalam menelaah dasar mekanisme cancer-related inflammation, model hewan yang banyak digunakan adalah mencit yang disuntikkan azoxymethane (AOM) yang merupakan prokarsinogen kolon, dilanjutkan pemberian 3 siklus dextran sulfate sodium (DSS); setelah 1-2 bulan, hampir $100 \%$ mencit menderita neoplasma kolon. ${ }^{7,20}$ Pada induksi kanker kolorektal dengan AOM dan DSS, mencit galur BALB/c memiliki insidensi tumor tertinggi jika dibandingkan dengan galur $\mathrm{C} 3 \mathrm{H} / \mathrm{He}, \mathrm{C} 57 \mathrm{BL} / 6 \mathrm{~J}$ dan DBA/2. ${ }^{18}$

Hingga saat ini, belum ditemukan obat antikanker dan strategi pengobatan yang ampuh yang dapat menghancurkan sel ganas secara menyeluruh dan selektif. Transformasi neoplastik secara umum merupakan proses panjang yang berlangsung relatif lama, maka upaya kemoprevensi dapat digunakan untuk mengintervensi patogenesis kanker, terutama pada fase awal onkogenesis. Banyak substansi yang terdapat dalam makanan sehari-hari efektif dalam mencegah kanker. Banyak komponen kimia organik dalam tumbuhan yang disebut fitokimia, menunjukkan potensi fitopreventif, selain sebagai antioksidan. Salah satu pendekatan yang menjanjikan dalam mempelajari mekanisme fitopreventif fitokimia adalah pemeriksaan efeknya terhadap komponen spesifik signal transduction network yang sering kali dideregulasi dalam banyak sel kanker. ${ }^{21}$ 


\section{Research Article}

Buah merah (Pandanus conoideus Lam.) adalah tumbuhan yang berasal dari Papua dan banyak dipakai untuk pengobatan kanker, arteriosklerosis, rheumatoid arthritis dan stroke. ${ }^{22}$ Buah merah merupakan sumber antioksidan eksogen yang banyak mengandung $\beta$-karoten, $\beta$ kriptosantin, $\alpha$-tokoferol, senyawa fenolik dan flavonoid. ${ }^{22,23}$ Secara empiris, khasiat buah merah sudah banyak terbukti, tapi penelitian secara in vivo dan in vitro belum banyak dilakukan. $^{23-25}$

Penelitian-penelitian sebelumnya menunjukkan bahwa pemberian minyak buah merah menyebabkan peningkatan proliferasi limfosit dan penurunan kadar interferon- $\gamma$ (IFN- $\gamma$ ) pada mencit yang diinokulasi dengan Listeria monocytogenes. ${ }^{26,27}$ Pemberian minyak buah merah pada mencit yang diinduksi kolitis dengan DSS terbukti dapat meningkatkan proliferasi leukosit non-T dan menurunkan derajat keparahan kolitis yang dinilai melalui skor klinis kolitis. Pada penelitian ini didapatkan bahwa dosis optimal minyak buah merah adalah $0,1 \mathrm{ml}$ atau $4 \mathrm{ml} / \mathrm{kg}$ BB yang merupakan dosis minimal yang sudah dapat memberikan efek proliferasi leukosit non$\mathrm{T}^{28}$

Penelitian Waspodo dan Nishigaki memperlihatkan bahwa minyak buah merah dapat menghambat pertumbuhan sel kanker paru-paru (lung cancer A549 cell line) secara in vitro. ${ }^{29}$ Mun'im et al. menemukan bahwa pemberian sari buah merah 0,21 ml/200 g dapat menghambat karsinogenesis paru-paru pada tikus betina Sprague-Dawley yang diinduksi 1,12dimethylbenz[a]anthracene (DMBA). ${ }^{30}$ Penelitian pada breast cancer $T 47 D$ cell line dan colorectal cancer CC 531 cell line, menunjukkan bahwa sari buah merah menghambat pertumbuhan sel kanker dengan LC $_{50}$ untuk sel kanker payudara 600 ppm dan LC $_{50}$ untuk sel kanker usus besar 200 ppm. ${ }^{31}$

Tanaman buah merah dengan kandungan tinggi fitokimia yang berfungsi sebagai antioksidan dan imunomodulator diharapkan dapat berperan sebagai agen fitopreventif dengan menghambat jalur selular dan molekular yang melibatkan IL-6 dalam patogenesis inflammationrelated cancer pada mencit galur BALB/c jantan yang diinduksi CAC dengan AOM dan DSS.

\section{Metode}

Desain penelitian ini adalah eksperimental laboratorik, komparatif, dengan rancangan acak lengkap (RAL). Penelitian dilaksanakan di Laboratorium Pemeliharaan dan Penelitian Hewan Coba serta Laboratorium Pusat Penelitian Ilmu Kedokteran (PPIK), Fakultas Kedokteran (FK) Universitas Kristen Maranatha (UKM) pada bulan Mei-November 2013. Objek penelitian adalah mencit (Mus musculus L.) galur BALB/c jantan, berumur 8 minggu, dengan berat badan $25 \pm 2$ gram yang diperoleh dari Laboratorium Pemeliharaan dan Penelitian 


\section{Research Article}

Hewan Coba PPIK FK UKM. Penelitian ini telah mendapatkan persetujuan dari Komite Etik Penelitian Kesehatan Fakultas Kedokteran Universitas Padjadjaran-RSUP Dr. Hasan Sadikin Bandung (No. 257/FKUP-RSHS/KEPK/Kep./EC/2011) dengan memperhatikan prinsip 3R yaitu replacement, reduction dan refinement.

Analisis data hasil pemeriksaan kadar IL-6 serum dilakukan menggunakan uji ANOVA satu arah dengan $\alpha=0,05$; dilanjutkan uji Tukey HSD dengan tingkat kepercayaan 95\%. Analisis data skor analisis histopatologis kolon menggunakan uji Kruskal-Wallis dengan $\alpha=0,05$; dilanjutkan uji Mann-Whitney dengan tingkat kepercayaan 95\%.

Bahan uji adalah minyak buah merah yang diproduksi PT Papua Herbal Sejahtera (bekerja sama dengan Balai Besar Industri Agro, Bogor dan $M \&$ K Laboratories Inc, Japan) dan telah diekspor ke Jepang; azoxymethane (AOM) (Wako-100 mg); dextran sulfate sodium (DSS) (AMRESCO-0918-50 g); Mouse IL-6 ELISA (R\&D Systems, USA); bahan untuk pembuatan preparat histologik dengan pewarnaan HE.

Mencit yang telah diadaptasikan di laboratorium selama 7 hari, dibagi secara acak menjadi 4 kelompok ( $\mathrm{n}=6$ ): (1) kelompok kontrol negatif: mencit disuntik 0,4 ml aquabidest dosis tunggal secara intraperitoneal. Pada hari ke-6 diberikan aquadest ad libitum selama 5 hari, dilanjutkan dengan pemberian aquabidest per oral $0,1 \mathrm{ml} /$ hari menggunakan sonde lambung selama 16 hari. Siklus pemberian aquadest ad libitum dan aquabidest per oral diulang 2 kali, hingga total 3 kali; (2) kelompok kontrol buah merah: mencit disuntik 0,4 ml aquabidest dosis tunggal secara intraperitoneal. Pada hari ke-6 diberikan aquadest ad libitum selama 5 hari, dilanjutkan dengan pemberian minyak buah merah per oral $0,1 \mathrm{ml} /$ hari menggunakan sonde lambung selama 16 hari. Siklus pemberian aquadest ad libitum dan minyak buah merah per oral diulang 2 kali, hingga total 3 kali; (3) kelompok kontrol AOM dan DSS: mencit disuntik AOM $12 \mathrm{mg} / \mathrm{kg}$ BB dosis tunggal secara intraperitoneal. Pada hari ke-6 diberikan DSS 2,5\% (w/v) ad libitum selama 5 hari, dilanjutkan dengan pemberian aquabidest per oral $0,1 \mathrm{ml} / \mathrm{hari}$ menggunakan sonde lambung selama 16 hari. Siklus pemberian DSS 2,5\% (w/v) ad libitum dan aquabidest per oral diulang 2 kali, hingga total 3 kali; (4) kelompok perlakuan buah merah: mencit disuntik AOM $12 \mathrm{mg} / \mathrm{kg}$ BB dosis tunggal secara intraperitoneal. Pada hari ke-6 diberikan DSS 2,5\% (w/v) ad libitum selama 5 hari, dilanjutkan dengan pemberian minyak buah merah per oral $0,1 \mathrm{ml} /$ hari menggunakan sonde lambung selama 16 hari. Siklus pemberian DSS 2,5\% (w/v) ad libitum dan minyak buah merah per oral diulang 2 kali, hingga total 3 kali.

Pada hari ke-69, dilakukan pengambilan darah dari tiap mencit melalui sinus orbitalis sebanyak 0,5 ml, kemudian darah disentrifuga untuk diambil serumnya. Kadar IL-6 serum diukur menggunakan metode ELISA. Selanjutnya, semua mencit dikorbankan dengan dislokasi 


\section{Research Article}

servikal; kolon distal diambil untuk pembuatan preparat histologik dengan pewarnaan HE untuk analisis histopatologis. Kolon masing-masing mencit dibuatkan 3 slide preparat; dari tiap slide diambil 5 lokasi; dengan demikian, analisis histopatologis untuk masing-masing mencit dilakukan pada 15 area. Penentuan skor analisis histopatologis didasarkan pada kriteria yang digunakan oleh Santiago et $a l^{19}$ sebagai berikut: (1) Skor 1: normal (nukleus normal dan arsitektur normal), (2) Skor 2: kolitis tidak aktif atau kolitia aktif (kriptitis, invasi neutrofil ke kelenjar, abses kripta, mikroabses), (3) Skor 3: low-grade dysplasia (LGD; hiperkromasia, rasio nukleus/sitoplasma meningkat, batas nukleus tidak regular dan jumlah mitosis normal meningkat), (4) Skor 4: high-grade dysplasia (HGD; hiperkromasia, rasio nukleus/sitoplasma meningkat, batas nukleus tidak regular, jumlah mitosis normal meningkat dan arsitektur mukosa kripta hilang) dan (5) Skor 5: karsinoma (hiperkromasia, rasio nukleus/sitoplasma meningkat, batas nukleus tidak regular, arsitektur mukosa kripta hilang dan jumlah mitosis atipik meningkat).

\section{Hasil}

Rerata kadar IL-6 serum masing-masing kelompok dapat dilihat pada Tabel 1.

Tabel 1 Rerata Kadar IL-6 Serum

\begin{tabular}{llc}
\hline Kelompok & Rerata Kadar IL-6 Serum $(\mathbf{p g} / \mathbf{m l}) \pm \mathbf{s d}$ & ilai p \\
\hline Kontrol Negatif & $\pm 3,916$ & \\
\hline Kontrol Buah Merah & $8 \pm 2,408$ & 000 \\
\hline Kontrol AOM/DSS & $4 \pm 7,094$ & \\
\hline Perlakuan Buah Merah & $4 \pm 5,416$ & \\
\hline \multicolumn{2}{l}{$\begin{array}{l}\text { Keterangan: } \\
\text { sd = standar deviasi }\end{array}$}
\end{tabular}

Analisis statistik menggunakan uji ANOVA satu arah menghasilkan $F_{\text {hitung }}=16,252$ $\left(>\mathrm{F}_{\text {tabel }(3.20 .0,05)}=3,10\right)$ dan $\mathrm{p}=0,000(<\alpha=0,05)$. Hal ini menunjukkan perbedaan signifikan rerata kadar IL-6 serum pada sedikitnya sepasang kelompok perlakuan. Analisis post hoc dengan uji Tukey HSD menunjukkan bahwa antara kelompok kontrol negatif, kelompok kontrol buah merah dan kelompok perlakuan buah merah tidak terdapat perbedaan rerata kadar IL-6 serum yang signifikan secara statistik; sedangkan, antara kelompok kontrol AOM/DSS dengan kelompok kontrol negatif, kelompok kontrol buah merah dan kelompok perlakuan buah merah terdapat perbedaan rerata kadar IL-6 serum yang sangat signifikan $(p=0,000)$.

Pemeriksaan histologik dilakukan pada 15 area per mencit menggunakan mikroskop cahaya dengan pembesaran 100 kali. Gambaran histologik kolon mulai dari yang diklasifikasikan 
Research Article

sebagai normal, kolitis, LGD, HGD dan karsinoma dengan karakteristiknya masing-masing diperlihatkan pada Gambar 1-Gambar 8.

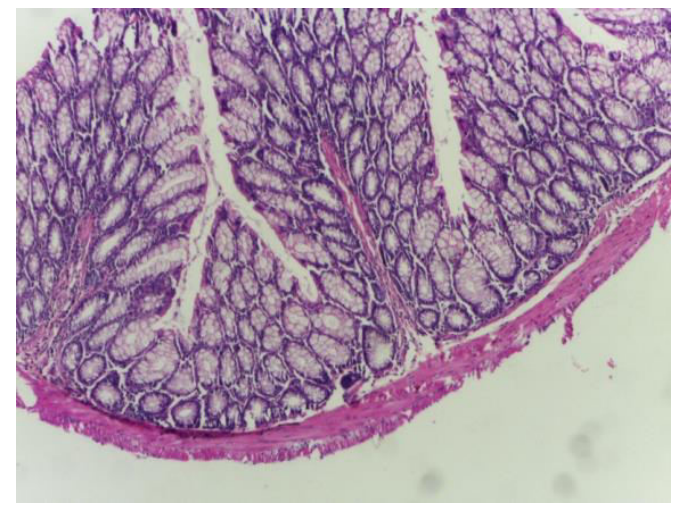

Gambar 1 Kolon dari Kelompok Kontrol Negatif Memperlihatkan Gambaran Normal dengan arsitektur kripta yang normal dan tidak tampak infiltrasi neutrofil atau sel inflamasi $(100 \mathrm{x})$

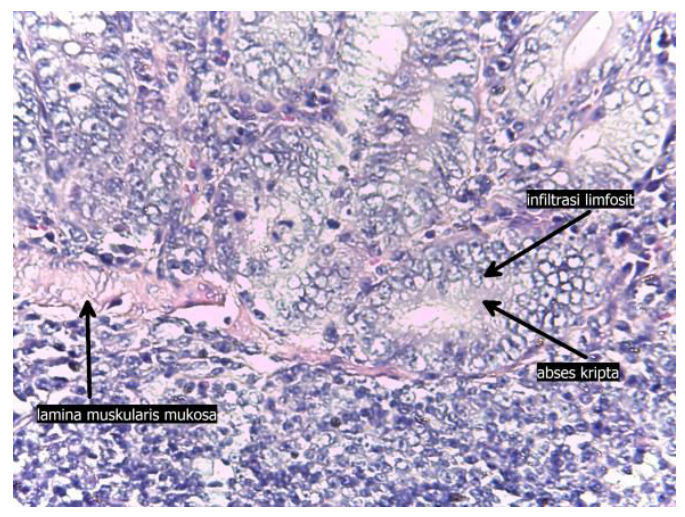

Gambar 2 Kolon dari Kelompok Kontrol AOM/DSS Memperlihatkan Gambaran Kolitis Ulseratif dengan abses kripta(400x)

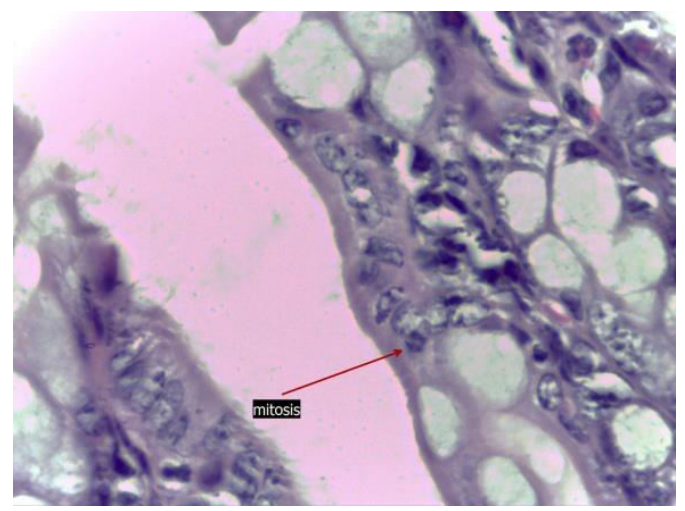

Gambar 3 Kolon dari Kelompok Perlakuan Buah Merah Memperlihatkan Gambaran Low-Grade Dysplasia yang ditandai hiperkromasia, rasio nukleus/sitoplasma meningkat, batas nukleus tidak regular dan jumlah mitosis normal sel epitel usus meningkat (1000x) 


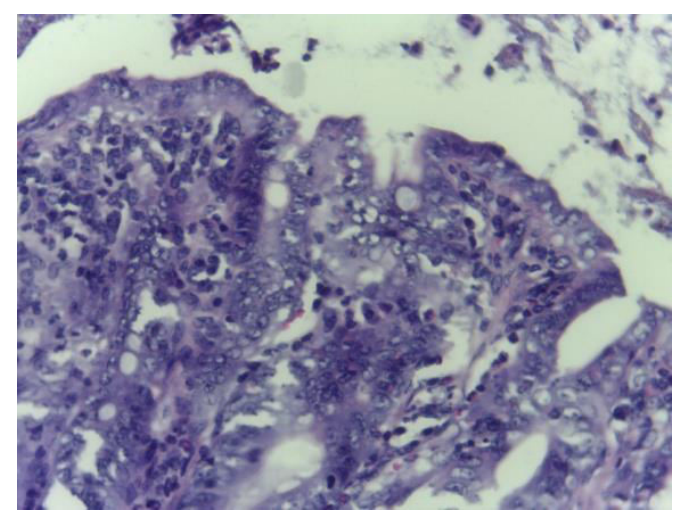

Gambar 4 Kolon dari Kelompok Perlakuan Buah Merah Memperlihatkan Gambaran High-Grade Dysplasia yang ditandai hiperkromasia, rasio nukleus/sitoplasma meningkat, batas nukleus tidak regular, jumlah mitosis normal sel epitel usus meningkat dan arsitektur mukosa kripta hilang (400x)

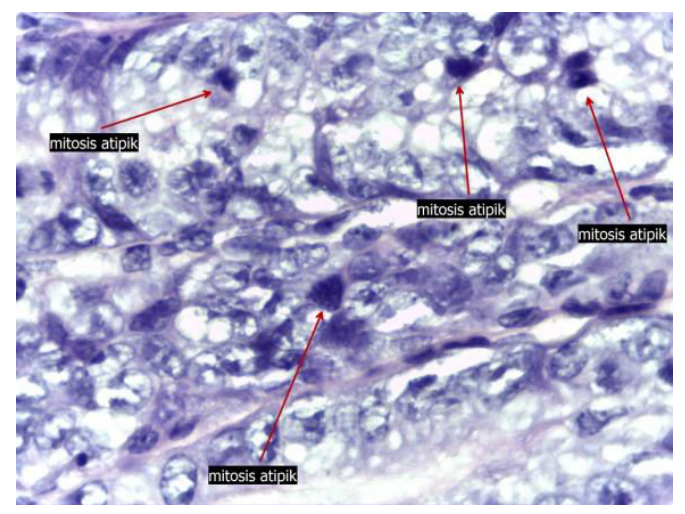

Gambar 5 Kolon dari Kelompok Kontrol AOM/DSS Memperlihatkan Gambaran Karsinoma dengan mitosis atipik dalam sel epitel usus (1000x)

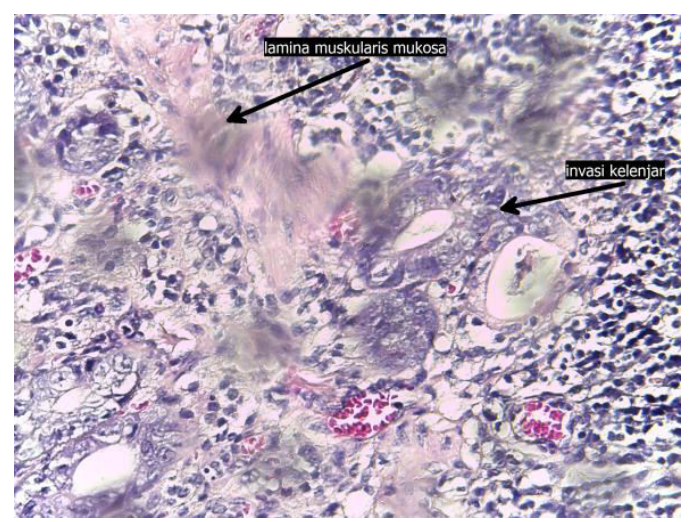

Gambar 6 Kolon dari Kelompok Kontrol AOM/DSS Memperlihatkan Gambaran Karsinoma dengan kelenjar yang menginvasi tunika submukosa (400x) 


\section{Research Article}

Skor analisis histopatologis dari 15 area per mencit dirata-ratakan. Selanjutnya, skor analisis histopatologis kolon masing-masing kelompok dirata-ratakan, sehingga diperoleh rerata skor analisis histopatologis kolon masing-masing kelompok yang dapat dilihat pada Tabel 2.

Tabel 2 Rerata Skor Analisis Histopatologis Kolon

\begin{tabular}{lll}
\hline \multicolumn{1}{c}{ Kelompok } & Rerata Skor Analisis Histopatologis \pm sd & Nilai p \\
\hline & & \\
Kontrol Negatif &, 070 & \\
Kontrol Buah Merah & $\pm 0,035$ & 0,000 \\
Kontrol AOM/DSS & $\pm 0,369$ & \\
Perlakuan Buah Merah & $\pm 0,206$ & \\
& & \\
\multicolumn{1}{c}{ Keterangan: } \\
$\quad$ sd = standar deviasi
\end{tabular}

Uji Kruskal-Wallis menghasilkan $\mathrm{p}=0,000 \quad(<\alpha=0,05)$ menunjukkan perbedaan signifikan skor analisis histopatologis kolon pada sedikitnya sepasang kelompok perlakuan. Selanjutnya, analisis post hoc dengan uji Mann-Whitney menunjukkan bahwa antara kelompok kontrol AOM/DSS dengan kelompok kontrol negatif, kelompok kontrol buah merah dan kelompok perlakuan buah merah terdapat perbedaan skor analisis histopatologis yang sangat signifikan secara statistik $(\mathrm{p}=0,002)$.

\section{Diskusi}

Penemuan leukosit dalam tumor oleh Rudolf Virchow pada tahun 1863 merupakan indikasi pertama terdapatnya hubungan antara inflamasi dan kanker. ${ }^{8}$ Dewasa ini, peranan inflamasi dalam tumorigenesis secara umum telah diterima, juga telah terbukti bahwa inflammatory microenvironment merupakan komponen esensial pada semua tumor, tanpa terkecuali pada beberapa jenis tumor yang belum terbukti mempunyai hubungan kausal langsung dengan inflamasi. ${ }^{32-36}$

Stres oksidatif dan kerusakan jaringan akibat inflamasi diketahui sebagai dua faktor paling penting yang terlibat dalam karsinogenesis. ${ }^{37}$ Peningkatan pembentukan reactive oxygen and nitrogen species (RONS) dalam lumen usus dan paparan berkesinambungan RONS terhadap mukosa mengakibatkan kerusakan oksidatif DNA sel epitel, sehingga memicu timbulnya mutasi genetik. ${ }^{38}$ Kadar premutagenic DNA adduct 8-hydroxydeoxyguanosine yang tinggi pada jaringan kolon dan plasma pasien IBD menunjukkan peranan stres oksidatif dalam karsinogenesis kolorektal. ${ }^{39}$ Pada satu sel kanker kolorektal diperkirakan terjadi sedikitnya 11.000 mutasi DNA yang mungkin disebabkan oleh RONS. ${ }^{40}$ Mutasi pada gen yang bertanggung jawab untuk mengontrol siklus sel atau sistem reparasi DNA mengakibatkan sel 


\section{Research Article}

berproliferasi secara otonom, yang mana merupakan mekanisme inisial karsinogenesis kolorektal. Selanjutnya, terjadi inflamasi kronik yang mengubah arsitektur normal sel epitel kolon menjadi displasia. Perubahan histologik tersebut merupakan prekursor kanker kolorektal. ${ }^{38}$

Model kanker kolorektal dengan induksi kimiawi yang kerap digunakan untuk mempelajari mekanisme karsinogenesis dan upaya intervensi kemopreventif adalah model AOM/DSS. Model ini sangat bernilai karena reproduksibilitas dan potensinya yang tinggi, juga aplikasinya yang sederhana dan relatif mudah dikerjakan. ${ }^{40}$ AOM merupakan prokarsinogen indirek yang kuat dan stabil. AOM diubah oleh sitokrom p450 menjadi methylazoxymethane (MAM) yang dapat memproduksi DNA adducts dan menyebabkan inisiasi tumor. ${ }^{42}$ AOM juga merangsang pembentukan O-6-methyl-guanine yang dapat merusak DNA, menyebabkan transisi asam amino G-A (guanin-adenin). ${ }^{43}$ DSS adalah polisakarida sintetik yang dapat menginduksi kolitis melalui mekanisme disrupsi barier usus, sehingga makrofag di lamina propria dapat berinteraksi dengan bakteri usus dan mengaktifkan sistem imun. ${ }^{44}$ Pelepasan reactive oxygen species (ROS) oleh sel imun alami mengakibatkan peningkatan stres oksidatif

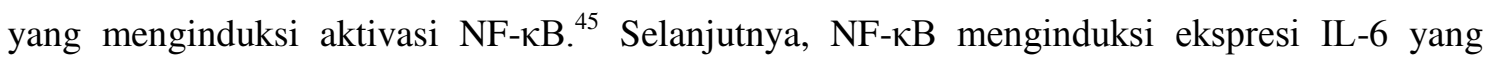
merangsang pertumbuhan sel kanker. IL-6 sendiri kemudian merangsang aktivasi NF- $\kappa \mathrm{B},{ }^{4}$ sehingga terbentuk suatu positive feedback (feedforward) loop yang akan menginduksi kerusakan DNA dan sel, serta mempromosikan proliferasi dan transformasi sel. ${ }^{46}$

Pada penelitian ini, pemeriksaan dengan metode ELISA terhadap kadar IL-6 serum menghasilkan rerata kadar tertinggi pada kelompok kontrol AOM/DSS (diinduksi CAC). Hasil ini sesuai dengan hasil studi klinis, yang mana kadar IL-6 yang tinggi ditemukan dalam darah tepi penderita IBD dan penderita kanker kolon, serta sediaan kanker kolon ${ }^{12,47,48}$ dan pada penderita UC yang berkembang menjadi CAC. ${ }^{49}$ IL-6 signaling merupakan target terapi kanker kolon pada manusia. ${ }^{12}$ IL-6 memodulasi ekspresi kemokin dan molekul adhesi serta apoptosis, menekan infiltrasi neutrofil dan meningkatkan akumulasi leukosit mononuklear. ${ }^{50}$

Selanjutnya, analisis statistik terhadap rerata kadar IL-6 serum menghasilkan perbedaan yang sangat signifikan $(\mathrm{p}=0,000)$ antara kelompok perlakuan buah merah dan kelompok kontrol AOM/DSS. Hasil penelitian ini menunjukkan bahwa pemberian minyak buah merah pada mencit kelompok perlakuan buah merah menurunkan kadar IL-6 serum secara sangat signifikan dan nilainya mendekati nilai pada mencit kelompok kontrol negatif. Diduga fitokimia yang terkandung dalam buah merah menghambat aktivasi NF- $\mathrm{BB}$ melalui penghambatan fosforilasi

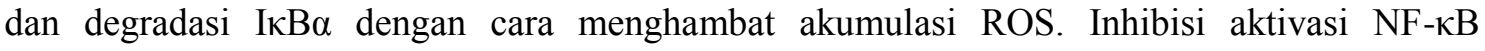
mengakibatkan penurunan produksi IL-6 oleh sel mieloiddan penurunan ekspresi gen 


\section{Research Article}

antiapoptotik (prosurvival) yang berarti peningkatan apoptosis sel. IL-6 juga sangat penting bagi diferensiasi dan survival sel T, sehingga penurunan kadar IL-6 akan mengurangi rekrutmen sel $\mathrm{T}$ yang merupakan komponen tumor microenvironment dan selanjutnya mengurangi proses cancer-related inflammation. Kadar IL-6 berkorelasi dengan ukuran tumor pada kanker kolorektal. ${ }^{12}$ Modulasi ekspresi IL-6 mempunyai efek yang signifikan terhadap pertumbuhan tumor pada model CAC, menunjukkan peran sitokin ini sebagai faktor tropik untuk sel epitel neoplastik. $^{20}$

Perubahan histopatologik paling dini yang ditemukan pada proses yang menghubungkan inflamasi kronik dengan kanker adalah displasia. ${ }^{18}$ Displasia gastrointestinal didefinisikan secara mikroskopis sebagai penggantian sel epitel intestinal normal oleh sel epitel neoplastik, tapi noninvasif. Dengan ditemukannya displasia, mungkin sudah terjadi kanker kolorektal. ${ }^{51}$ Pada penelitian ini, histopatologi kolon diklasifikasikan menjadi negatif untuk displasia atau positif untuk displasia atau karsinoma. Negatif untuk displasia meliputi normal (skor 1), kolitis tidak aktif atau kolitis aktif (skor 2). Positif untuk displasia meliputi low-grade dysplasia (skor 3), high-grade dysplasia (skor 4) dan karsinoma (skor 5). Kriteria normal meliputi nukleus normal dan arsitektur normal; kriteria kolitis aktif meliputi kriptitis, invasi neutrofil ke kelenjar, abses kripta dan mikroabses. Kriteria low-grade dysplasia (LGD) meliputi hiperkromasia, rasio nukleus/sitoplasma meningkat, batas nukleus tidak regular dan jumlah mitosis normal meningkat. Kriteria high-grade dysplasia (HGD) meliputi kriteria low-grade dysplasia ditambah arsitektur mukosa kripta hilang. Pada LGD, nukleus terletak di separuh basal sel epitel; sedangkan pada HGD, nukleus tersebar acak di antara separuh basal dan separuh apikal. Kriteria karsinoma meliputi kriteria HGD, tapi jumlah mitosis normal meningkat digantikan jumlah mitosis atipikal meningkat. ${ }^{19}$

Rerata skor analisis histopatologis kolon tertinggi didapatkan pada kelompok kontrol AOM/DSS $(4,422 \pm 0,369)$ dan hasil analisis statistik menunjukkan perbedaan skor analisis histopatologis yang sangat signifikan $(\mathrm{p}=0,002)$ antara kelompok perlakuan buah merah $(3,034 \pm 0,206)$ dan kelompok kontrol AOM/DSS. Hasil penelitian ini sesuai dengan temuan Grivennikov et al. pada mencit dengan defisiensi IL-6, yang mana didapatkan adenoma yang lebih sedikit dan berukuran lebih kecil dibandingkan pada mencit wild type yang mendapatkan perlakuan yang sama. ${ }^{50}$

NF-кB penting untuk survival perkembangan limfosit dengan menginduksi ekspresi beberapa gen survival, antara lain anggota famili Bcl-2 ${ }^{14,16}$ juga IL-6. Keduanya penting dalam mempertahankan inflammatory microenvironment yang dapat memacu survival dan proliferasi sel yang telah mengalami mutasi. Sel inflamasi juga meningkatkan derajat mutasi melalui 


\section{Research Article}

perannya sebagai sumber reactive species yang dapat menginduksi kerusakan DNA dan ketidakstabilan genomik.

Hasil dari penelitian ini menunjukkan bahwa pemberian minyak buah merah pada mencit yang diinduksi CAC dengan AOM/DSS (kelompok perlakuan buah merah) menurunkan kadar IL-6 serum dan skor analisis histopatologis kolon. Fitokimia yang terkandung dalam buah merah antara lain karotenoid dan $\alpha$-tokoferol, juga senyawa fenolik dan flavonoid. ${ }^{22,23}$ Karotenoid yang terkandung dalam buah merah adalah $\alpha$-karoten, $\beta$-karoten dan $\beta$ kriptosantin. ${ }^{29}$ Banyak penelitian telah melaporkan peranan karoten dan vitamin E sebagai antioksidan dan antiinflamasi. Beberapa studi epidemiologis menunjukkan bahwa orang yang mengonsumsi sayur dan buah yang kaya akan karotenoid memiliki risiko terkena kanker kolorektal yang lebih rendah. ${ }^{52}$ Pemberian vitamin E $200 \mathrm{IU} /$ hari juga terbukti dapat menurunkan insidensi kanker kolorektal. ${ }^{45}$ Alfa-tokoferol merupakan salah satu bentuk vitamin E dengan potensi antioksidan yang kuat. Mekanisme kerja vitamin E secara umum adalah dengan mencegah akumulasi radikal bebas dan aktivasi endonuklease. Selain itu, karena sifatnya yang larut dalam lemak, $\alpha$-tokoferol melindungi membran sel dari peroksidasi lipid. Vitamin E menurunkan pelepasan ROS oleh monosit, juga menghambat pelepasan sitokin proinflamasi, termasuk IL-6 oleh monosit dan makrofag. ${ }^{53}$ Beberapa penelitian in vitro menunjukkan bahwa pemberian vitamin $\mathrm{C}$ dan vitamin $\mathrm{E}$ ( $\alpha$-tokoferol) pada sel dendritik yang distimulasi dengan lipopolisakarida (LPS) dapat menurunkan produksi RONS, menghambat

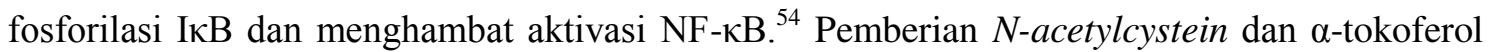
pada neutrofil yang dirangsang LPS dapat menghambat aktivasi I $\kappa$ kinase, mencegah translokasi NF-kB ke dalam nukleus dan menurunkan produksi sitokin proinflamasi. ${ }^{55}$

Karotenoid dan asam retinoat diduga dapat meregulasi faktor transkripsi seperti NF- $\mathrm{kB}$ dan activator protein 1 (AP-1). AP-1 adalah faktor transkripsi redox-sensitive yang terlibat dalam regulasi pertumbuhan sel. ${ }^{56}$ Pemberian $\beta$-karoten pada makrofag yang distimulasi LPS menurunkan ekspresi iNOS, TNF- $\alpha$ IL-1 $\beta$ dan COX-2, serta menurunkan produksi NO dan

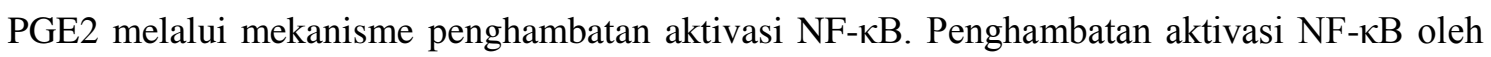
$\beta$-karoten dicapai melalui penghambatan fosforilasi dan degradasi $\mathrm{I} \kappa \mathrm{B} \alpha$ melalui penghambatan akumulasi ROS. Pemberian $\beta$-karoten pada sel yang mengalami stres oksidatif dapat menekan aktivasi NF- $\kappa B$ serta produksi sitokin proinflamasi seperti IL-6 dan TNF- $\alpha .{ }^{45}$

Buah merah juga mengandung senyawa fenolik dan flavonoid. ${ }^{22}$ Senyawa fenolik

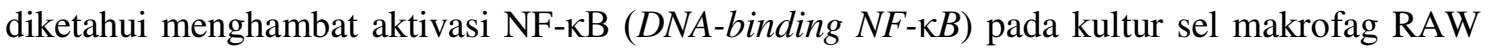
264.7 yang diinduksi LPS, sehingga tidak terjadi induksi ekspresi TNF- $\alpha .{ }^{57}$ Penelitian-penelitian 


\section{Research Article}

terhadap flavonoid memperlihatkan bahwa flavonoid menekan produksi NO dan menghambat aktivasi NF- $\mathrm{KB} .{ }^{58}$

Pada penelitian ini didapatkan bahwa pada mencit model CAC yang diberikan minyak buah merah (kelompok perlakuan buah merah), didapatkan rerata kadar IL-6 serum dan skor analisis histopatologis kolon yang lebih rendah secara sangat signifikan dibandingkan mencit model CAC yang tidak diberikan minyak buah merah (kelompok kontrol AOM/DSS). Penurunan tersebut diduga disebabkan fitokimia yang terkandung dalam buah merah dapat menghambat aktivasi NF-кB melalui penghambatan aktivasi IKK. Inhibisi aktivasi IKK berarti

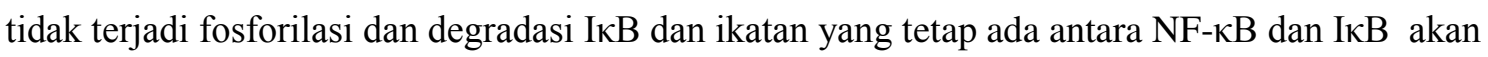
mencegah translokasi NF- $\mathrm{KB}$ ke dalam nukleus, sehingga tidak terjadi transkripsi gen-gen mediator inflamasi. Jalur NF-kB dianggap sebagai jalur utama untuk respon terhadap stres oksidatif. Penelitian-penelitian menunjukkan hampir seluruh jalur yang menuju aktivasi NF-kB dihambat oleh berbagai aktioksidan. ${ }^{56}$ Inhibisi aktivasi NF- $\mathrm{kB}$ mencegah ekspresi mediator inflamasi sehingga menghambat terjadinya inflammation-related colorectal carcinogenesis.

Efek kemopreventif dari fitokimia merupakan gabungan dari beberapa mekanisme, meliputi hambatan aktivasi metabolik karsinogen dan/atau hambatan pengikatan DNA oleh karsinogen, stimulasi detoksifikasi, reparasi kerusakan DNA, supresi proliferasi sel dan supresi metastasis atau angiogenesis, induksi diferensiasi atau apoptosis sel premalignant atau sel ganas. $^{21}$ Berdasarkan hasil penelitian ini, disimpulkan bahwa mekanisme molekular fitopreventif minyak buah merah meliputi supresi proliferasi sel dan induksi apoptosis sel melalui modulasi signal transduction pathways yang melibatkan IL-6 sebagai akibat penghambatan aktivasi NF-кB.

Komponen cell signaling network, terutama yang berhubungan dengan redox-sensitive $N F-\kappa B$ terlibat dalam patogenesis inflamasi. Supresi abnormally amplified inflammatory signaling dan restorasi antioksidan dapat dijadikan strategi dalam upaya kemoprevensi. Buah merah memiliki kedua karakteristik tersebut, yakni antiinflamasi dengan menghambat aktivasi $\mathrm{NF}-\mathrm{\kappa B}$ dan antioksidan dengan beraksi sebagai reactive species scavenger.

\section{Simpulan}

Hasil penelitian menyimpulkan bahwa pemberian minyak buah merah menurunkan kadar IL-6 serum dan menurunkan skor analisis histopatologis kolon mencit model CAC. Penelitian ini merupakan uji preklinis yang diperlukan sebagai prasyarat sebelum dilakukan uji klinis untuk mengembangkan buah merah menjadi fitofarmaka yang dapat digunakan untuk mencegah inflammation-related carcinogenesis. 


\section{Ucapan Terima Kasih}

Penelitian ini didanai Hibah Penelitian Disertasi Doktor 2013.

\section{DAFTAR PUSTAKA}

1. Meira LB, Bugni JM, Green SL, Lee C, Pang B, Borenshtein D, et al. DNA Damage Induced by Chronic Inflammation Contributes to Colon Carcinogenesis in Mice. J Clin Invest. 2008; 118(7): 2516-25

2. World Health Organization. Cancer. [document on the Internet: WHO Media centre]; 2011 February. [diunduh 27 Juni 2011]. Tersedia dari: http://www.who.int/mediacentre/factsheets/fs297/en

3. Departemen Kesehatan. Deteksi Dini Kanker Usus Besar. 2006 Oktober 1. [diunduh 12 November 2010]. Tersedia dari: http://www.litbang.depkes.go.id/aktual/kliping/KankerUsus011106.htm

4. Popivanova BK, Kitamura K, Wu Y, Kondo T, Kagaya T, Kaneko K, et al. Blocking TNF- $\alpha$ in Mice Reduces Colorectal Carcinogenesis Associated with Chronic Colitis. J Clin Invest. 2008; 118 (2): 560-70

5. Mantovani A. Cancer-related Inflammation: The Seventh Hallmark of Cancer. Am Soc Clin. Onc. 2009;723-726

6. Colotta F, Allavena P, Sica A, Garlanda C, Mantovani A. Cancer-related Inflammation, The Seventh Hallmark of Cancer: links to genetic instability. Carcinogenesis. 2009;30(7):1073-81

7. Danese S, Mantovani A. Inflammatory Bowel Disease and Intestinal Cancer: A Paradigm of The Yin-Yang Interplay Between Inflammation and Cancer. Oncogene. 2010;29:3313-23

8. Balkwill F, Mantovani A. Inflammation and Cancer: Back to Virchow? The Lancet. 2001;357(9255):539 -545

9. Karin M. The IкB kinase-A Bridge Between Inflammation and Cancer. Cell Research. 2008;18:334-342

10. Mantovani A, Allavena P, Sica A, Balkwill F. Cancer-related Inflammation. Nature. 2008; 454: 436-44.

11. Atreya R, Neurath MF. Signaling Molecules: The Pathogenic Role of the IL-6/STAT3 Trans Signaling Pathway in Intestinal Inflammation and In Colonic Cancer. Current Drug Targets. 2008;9(5):369-74

12. Becker C, Fantini MC, Schramm C, Lehr HA, Wirtz S, Nikolaev A, et al. TGF-beta Supresses Tumor Progression in Colon Cancer by Inhibition of IL-6 trans-signaling. Immunity. 2004;21:491-501

13. Mantovani A, Sica A, Locati M. Macrophage Polarization Comes of Age. Immunity. 2005; 23: 344-6

14. Chung YC, Chang YF. Serum interleukin-6 levels reflect the disease status of colorectal cancer. J Surg Oncol. 2003;82:222-26

15. Kai H, Kitadai Y, Kodama M, Cho S, Kuroda T, Ito M, et al. Involvement of Proinflammatory Cytokines IL-1 $\beta$ and IL-6 in Progression of Human Gastric Carcinoma. Anticancer Res. 2005;25:709-13

16. Li Y, De HC, Chen M, Deuring J, Gerrits MM, Smits R, et al. Disease-related Expression of the IL6/STAT3/SOC3 Signaling Pathway in Ulcerative Colitis and Ulcerative Colitis-Related Carcinogenesis. Gut. 2010; 59: 227-35

17. Greten FR, Eckmann L, Greten TF, et al. IKK $\beta$ Links Inflammation and Tumorigenesis in A Mouse Model of Colitis-Associated Cancer. Cell. 2004; 118:285-296

18. Tanaka T. Colorectal Carcinogenesis: Review of Human and Experimental Animal Studies. Journal of Carcinogenesis. 2009; 8(5): 1-19

19. Santiago C, Pagán B, Isidro AA, Appleyard CB. Prolonged Chronic Inflammation Progresses to Dysplasia In A Novel Rat Model of Colitis-Associated Colon Cancer. Cancer Res. 2007; 67(22): 10766-773

20. Burstein E, Fearon ER. Colitis and Cancer: A Tale of Inflammatory Cells and Their Cytokines. J Clin Invest. 2008;118(2):464-7

21. Surh YJ, Na HK. NF-kB and Nrf2 As Prime Molecular Targets for Chemoprevention and Cytoprotection with Anti-Inflammatory and Antioxidant Phytochemicals. Genes Nutr. 2008; 2: 313-7

22. Rohman A, Riyanto S, Yuniarti N, Saputra WR, Utami R, Mulatsih W. Antioxidant Activity, Total Phenolic, and Total Flavonoid of Extracts and Fractions of Red Fruit (Pandanus conoideus Lam.). International Food research Journal. 2010; 17: 97-106

23. Surono I, Nishigaki T, Endaryanto A, Waspodo P. Indonesian Biodiversities, from Microbes to Herbal Plants as Potential Functional Foods. Shinshu Daigaku Nogakubu Kiyo. 2008; 44(1-2): 23-27

24. Budi IM. Seri Agrisehat Buah Merah. Jakarta: Penebar Swadaya. 2005; 17-23

25. Yahya MH, Wiryanta BTMW. Khasiat dan Manfaat Buah Merah, si Emas Merah dari Papua. Jakarta: Agro Media Pustaka. 2005; 24-34

26. Ratnawati H, Khiong K, Soeng S, Sugeng SU, Kristiono E, Hudaya A. Pengaruh Ekstrak Buah Merah (Pandanus conoideus Lam.) terhadap Berat Limpa, Jumlah dan Proliferasi Limfosit pada Mencit Jantan Galur Swiss-Webster yang Diinokulasi Listeria monocytogenes. Disampaikan dalam KONAS XII dan PIN PAAI (Perhimpunan Ahli Anatomi Indonesia) Jakarta, 20-21 Juni 2008

27. Khiong K, Ratnawati H, Soeng S, Hudaya S, Griselda. Pengaruh Buah Merah terhadap Proliferasi Limfosit dan Kadar IFN- $\gamma$ pada Mencit yang Diinokulasi dengan Listeria monocytogenes. Simposium Penelitian Bahan Obat Alami XIV \& Muktamar XI PERHIPBA. 11-12 Agustus 2009. Jakarta 


\section{Research Article}

28. Khiong K, Ratnawati H, Soeng S, Sugeng SU, Angelie E, Nasseri M. Efek Immunomodulator Buah Merah (Pandanus conoideus Lam.) terhadap Berat Limpa, Jumlah dan Proliferasi Limfosit pada Mencit (Mus musculus) galur DDY yang Diinduksi Colitis dengan DSS. Disampaikan dalam KONAS XII dan PIN PAAI (Perhimpunan Ahli Anatomi Indonesia) Jakarta, 20-21 Juni 2008

29. Waspodo IS, Nishigaki T. Novel Chemopreventive Herbal Plant Buah Merah (Pandanus conoideus Lam.) for Lung Cancer. PATPI Conference in Bandung, July 17-18, 2007

30. Mun'im A, Andrajati R, Susilowati H. Uji Hambatan Tumorigenesis Sari Buah Merah (Pandanus connoideus Lam.) terhadap Tikus Putih Betina yang Diinduksi 7,12 DimetilBenz(a)Antrasen (DMBA). Majalah Ilmu Kefarmasian. 2006 3(3): 153-161

31. Moeljopawiro S, Anggelia MR, Ayuningtyas D, Widaryanti B, Sari Y, Budi IM. Pengaruh Sari Buah Merah (Pandaneus conoideus Lamk.) Terhadap Pertumbuhan Sel Kanker Payudara dan Sel Kanker Usus Besar. Berkala Ilmiah Biologi. 2007; 6(2): 121-130

32. Hanahan D, Weinberg RA. The Hallmarks of Cancer. Cell. 2000;100:57-70

33. Lin W, Karin M. A Cytokine-mediated Link Between Innate Immunity, Inflammation, and Cancer. J Clin Invest. 2007; 117(5):1175-83

34. Karin M, Greten FR. NF- $\mathrm{BB}$ Linking Inflammation and Immunity to Cancer Development and Progression. Nature Rev. Immunol. 2005;5:749-759

35. Bollrath J, Greten FR. IKK/NF-кB and STAT3 Pathways: Central Signaling Hubs in Inflammation-mediated Tumour Promotion and Metastasis. EMBO Reports. 2009;10(12):1314-19

36. Turner JR. The gastrointestinal tract. Dalam: Kumar V, Abbas AK, Fausto N, Aster JC, editor. Robbins and Cotran pathologic basis of disease. $8^{\text {th }}$ Edition. Philadelphia: Saunders Elsevier 2010;807-13; 822-26

37. Suzuki R, Kohno H, Sugie S, Nakagama H, Tanaka T. Strain Differences in the Susceptibility to Azoxymethane and Dextran Sodium Sulfate-Induced Colon Carcinogenesis in Mice. Carcinogenesis. 2006; 27(1): 162-9

38. Ribeiro ML, Priolli DG, Miranda DC, Arcari DP, Pedrazzoli J, Martinez CAR. Analysis of Oxidative DNA Damage in Patients with Colorectal Cancer. Clin Colorectal Cancer. 2008; 7(4): 267-72

39. Carrier J, Aghdassi E, Cullen J, Allard JP. Iron Supplementation Increases Disease Activity and Vitamin E Ameliorates The Effect in Rats with Dextran Sulfate Sodium-Induced Colitis. J Nutr. 2002;132:3146-50

40. De Robertis M, Massi E, Poeta ML, Carotti S, Morini S, Cecchetelli L, et al. The AOM/DSS Murine Model for The Study of Colon Carcinogenesis: From Pathway to Diagnosis and Therapy Studies. J Carcinog. 2011;10(9):1-27

41. Gackowski D, Banaszkiewicz Z, Rozalski R, Jawien A, Olinski R. Persistent Oxidative Stress in Colorectal Carcinoma Patient. Int J Cancer. 2007;101:395-7

42. Tanaka T, Kohno H, Suzuki R, Yamada Y, Sugie S, Mori H. A Novel Inflammation-related Mouse Colon Carcinogenesis Model Induced by Azoxymethane and Dextran Sodium Sulfate. Cancer Sci. 2003; 24(11): 96573

43. Gommeaux J, Cano C, Garcia S, Gironella M, Pietri S, Culcasi M, et al. Colitis and Colitis-Associated Cancer Are Exacerbated in Mice Deficient for Tumor Protein 53-induced nuclear protein 1. Mol Cell Biol. 2007;27(6):2215-28

44. Roessner A, Kuester D, Malfertheiner P, Schneider-Stock R. Oxidative Stress in Ulcerative Colitis-associated Carcinogenesis. Pathol Res Pract. 2008; 204: 511-24

45. Valko M, Rhodes CJ, Moncola J, Izakovic M, Mazura M. Free Radicals, Metals and Antioxidants in Oxidativestress-induced Cancer. Chemico-Biological Interactions. 2006; 160: 1-40

46. Federico A, Morgillo F, Tuccillo C, Ciardiello F, Loguercio C. Chronic Inflammation and Oxidative Stress in Human Carcinogenesis. Int J Cancer. 2007;121:2381-6

47. McLoughlin RM, Witowski J, Robson RL, Wilkinson TS, Hurst SM, Williams AS, et al. Interplay between Ifngamma and IL-6 Signaling Governs Neutrophil Trafficking and Apoptosis During Acute Inflammation. J Clin Invest. 2003; 112: 598-607

48. Atreya R, Mudter J, Finotto S, Mullberg J, Jostock T, Wirtz S, et al. Blockade of interleukin 6 Trans Signaling Supresses T-cell Resistance Against Apoptosis in Chronic Intestinal Inflammation: Evidence in Crohn's disease and Experimental Colitis In Vivo. Nature Med. 2000;6:583-8

49. Bollrath J, Phesse TJ, von Burstin VA, Putoczki T, Bennecke M, Bateman T, et al. gp130-mediated Stat3 Activation in Enterocytes Regulates Cell Survival and Cell-Cycle Progression During Colitis-Associated Tumorigenesis. Cancer Cell. 2009;15:91-102

50. Grivennikov S, Karin E, Terzic J, Mucida D, Yu GY, Vallabhapurapu S. IL-6 and Stat3 are Required for Survival of Intestinal Epithelial Cells and Development of Colitis-Associated Cancer. Cancer Cell. 2009;15:103-13

51. Potack J, Itzkowitz SH. Colorectal Cancer in Inflammatory Bowel Disease. Gut and Liver. 2008; 2(2): 61-73

52. Raju J, Swamy MV, Cooma I, Patiolla JMR, Pittman B, Reddy BS, et al. Low doses of $\beta$-carotene and lutein inhibit AOM-induced rat colonic ACF formation but high doses augment ACF incidence. Int J Cancer. 2005; 113: 798-802

53. Mora JR, Iwata M, von Andrian UH. Vitamin Effects on The Immune System: Vitamins A and D Take Centre Stage. Nature Rev Immunol. 2008; 8: 685-98 


\section{Research Article}

54. Tan PH, Sagoo P, Chan C, Yates JB, Campbell J, Beutelspacher SC, et al. Inhibition of NF- $\mathrm{BB}$ and oxidative Pathways in Human Dendritic Cells by Antioxidative Vitamins Generates Regulatory T cells. J Immunol. 2005; 174: 7633-44

55. Asehnoune K, Strassheim D, Mitra S, Kim JY, Abraham E. Involvement of Reactive Oxygen Species in Toll-like receptor 4-dependent Activation of NF-kB. J Immunol. 2004;172:2522-29

56. Palozza P, Serini S, Torsello A, Nicuolo FD, Piccioni E, Ubaldi V, et al. eta-carotene regulates NF- $\{$ kappa $\}$ B DNA-binding activity by A Redox Mechanism in Human Leukemia and Colon Adenocarcinoma Cells. J Nutr. 2003; 133: 381-8

57. Qiang MA, Krista K, Jianping Y, Bruce JC. Inhibition of nuclear factor- $\kappa B$ by phenolic antioxidant: Interplay between Antioxidant Signaling and Inflammatory Cytokine Expression. Mol Pharmacol. 2003; 62(2): 211-19

58. Hamalainen M, Nieminen R, Vuorela P, Heinonen M, Moilanen E. Anti-inflammatory effects of Flavonoids: Genistein, Kaempferol, Quercetin, and Daidzein Inhibit STAT1 and NF-кB Activation, Whereas Flavone, Isorhamnetin, Naringenin, and Pelargonidin Inhibit Only NF-кB Activation Along With Their Inhibitory Effect on iNOS Expression and NO Production in Activated Macrophages. Med of Inflammation. 2007; 1-10 